\title{
THE VOICE OF THE
}

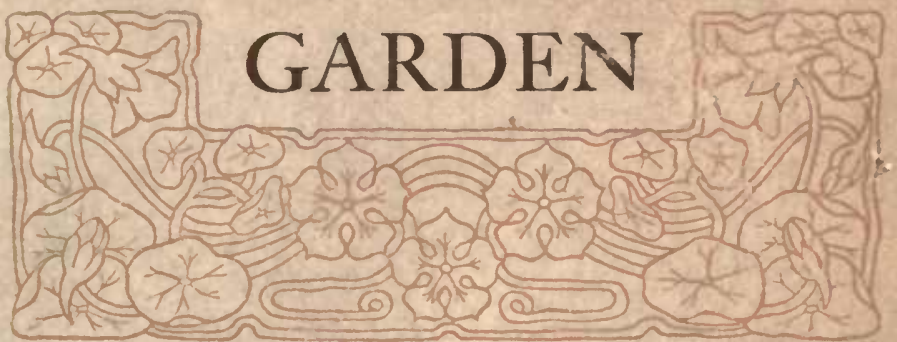

A BRAM - LINWOOD - URBAN 
1). 


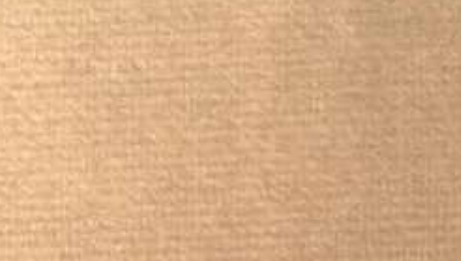

4he

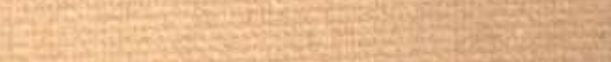

and

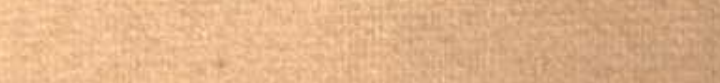

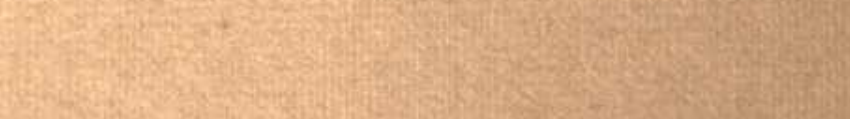

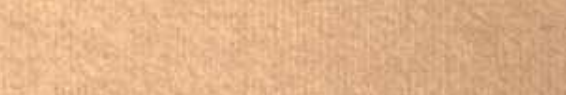

Q

What

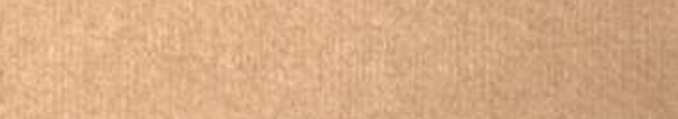

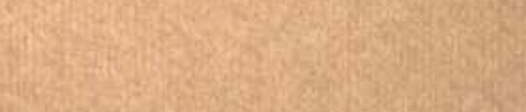

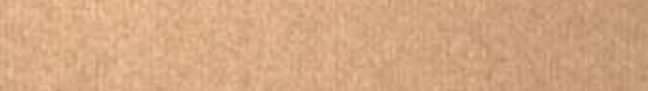

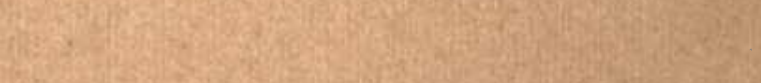

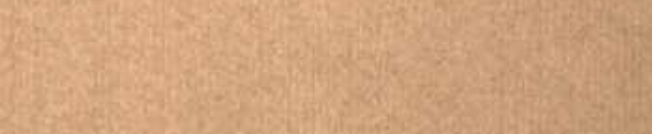

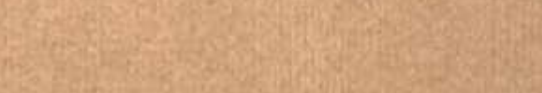

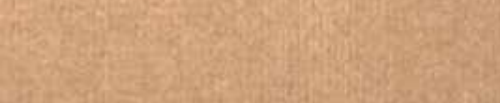

10

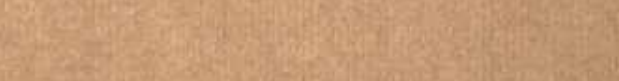

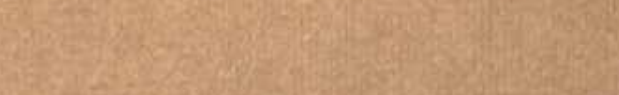

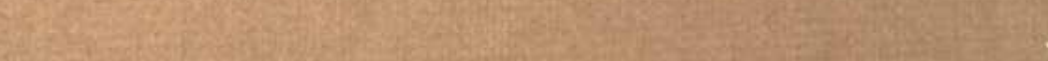




OF THIS FIRST EDITION OF THE VOICE OF THE GARDEN

KNOWN AS THE AUTHOR'S EDITION, THERE HAVE BEEN PRINTED TWO THOUSAND COPIES, OF WHICH NINETEEN HUNDRED AND FIFTY ARE FOR SALE. THIS COPY IS NO. 4 \&ZFOR PRESENTATION 


\section{BY THE SAME AUTHOR IN PREPARATION MY GARDEN OF DREAMS}




\section{THE VOICE OF THE GARDEN}





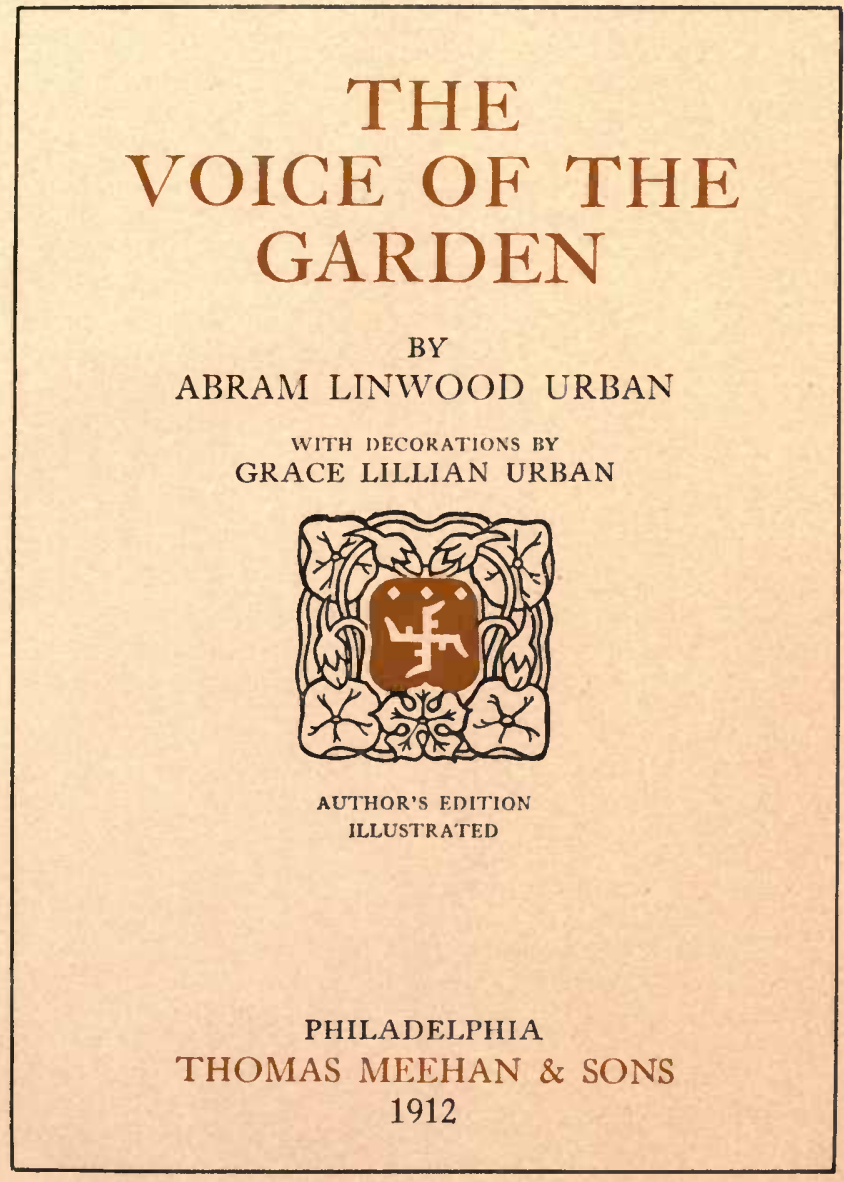


Copyright, 1912

By Thomas Meehan \& Sons

Germantown, Pa. 
To My Wife

THE FAIREST F LOWER

in My Garden 



\section{CONTENTS}

FOREWORD PAGE

FOREWORD . . . . . . . . . . . . . . 9

THE GARDEN . . . . . . . . . . . . . . 17

ART IN THE GARDEN . . . . . . . . . . . 29

SENTIMENT IN THE GARDEN . . . . . . . . ${ }_{5} \mathbf{I}$

VOICES IN THE GARDEN . . . . . . . . . . 7I

OUT FROM THE GARDEN . . . . . . . . . . 87

\section{ILLUSTRATIONS}

INTO THE GARDEN

ROSES AND HOLLYHOCKS

IN THE ROCK GARDEN . . . . . . . . . . 50

A GROUP OF FAVORITES . . . . . . . . . . 70 

FOREWORD 



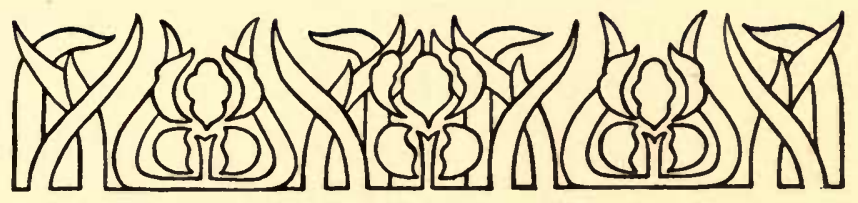

\section{FOREWORD}

I VERY gladly write a word in welcome to and in commendation of this little book. Its peculiar value I think will be found in the fact that it not only reports an experience and asks for sympathy, but also speaks a message and arrests attention. Its appeal lies not only to every garden lover, but equally to all the garden-less. The parson in his garden, in the cool of the day, thinks much of and cares much for the man in the street, in the city's dust and heat. His book is an invitation, sent forth with so much winning grace and so much loving wisdom that many will heed it if they will but read.

It must be true, if our faith in Christ is true, that the only cure of every human ill is spiritual. Poverty, suffering, disease, however cruel [9] 
and abhorrent in their obvious and bodily aspects, are still but superficial things if we think of them as related chiefly to the body. For the life is more than the meat even as the body itself is more than the raiment it puts on. We are of ten told that a starving body hinders and handicaps the soul. That may be true, and yet a starving soul is much more tragic than a starving body, and a starving soul is not apt to be overanxious about meat. The relief of bodily necessity, however much it presses as a duty on every Christian conscience, is by no means a sure method for the soul's relief. Bodily comfort, even more surely than bodily distress, dulls and deadens spiritual need. In the midst of our generous haste to feed and warm and heal we need to keep the balance true, and to preserve the proportion of our faith. We need to be reminded that man does not and cannot live by bread alone, and that social service, to be Christian, must minister to so as to satisfy man's spiritual hunger. This book will help us at this point. 
It will also help us further, for by a rich and FOREWORD delicate suggestiveness, it points out how full of opportunity "to the least of these, our brethren," the spiritual heritage given to us all in Christ actually is. The Kingdom of God is indeed a true democracy. St. Paul's claim that "all things are ours" by faith is only a comment on Christ's own promise to the meek that they shall inherit the earth. Faith is, after all, the true and the only method of possession. And faith is for the child. "Wherefore do ye spend money for that which is not bread, and your labor for that which satisfieth not?" It surely would not lessen the eagerness or spoil the science of our philanthropy if we gave more consistent and practical heed to this reminder. Equality of opportunity seems to be the broadest and best aspiration we can form for genuine and permanent economic social reconstruction. We do well to labor for it with our utmost diligence. But at the same time it would make for an increase of peace and health among us all, and for a deep and [ Ir] 
THE VOICE OF lasting reconciliation between classes, if we reminded ourselves that equality of opportunity in spiritual things is not a far-off vision, but a present fact, and an unalterable law by which God governs and disposes in His Church. The flowers and the birds are Christ's own chosen witnesses to the love that knows no respect of persons, and to the impartial grace which gives its choicest fruits "unto this last."

Every child loves flowers, and to flowerloving children the gates are open to the Kingdom and the Life.

May this book bring many to grow gardens in their homes and hearts.

Philip M. Rhinelander

Bishop of Pennsylvania

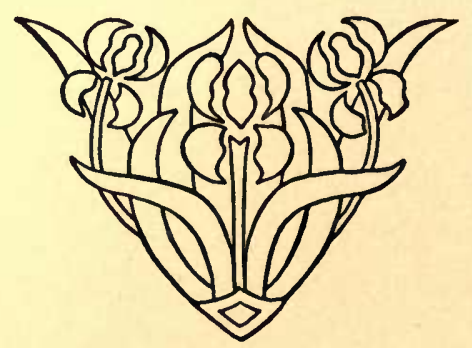


THE VOICE OF THE GARDEN 

THE GARDEN 


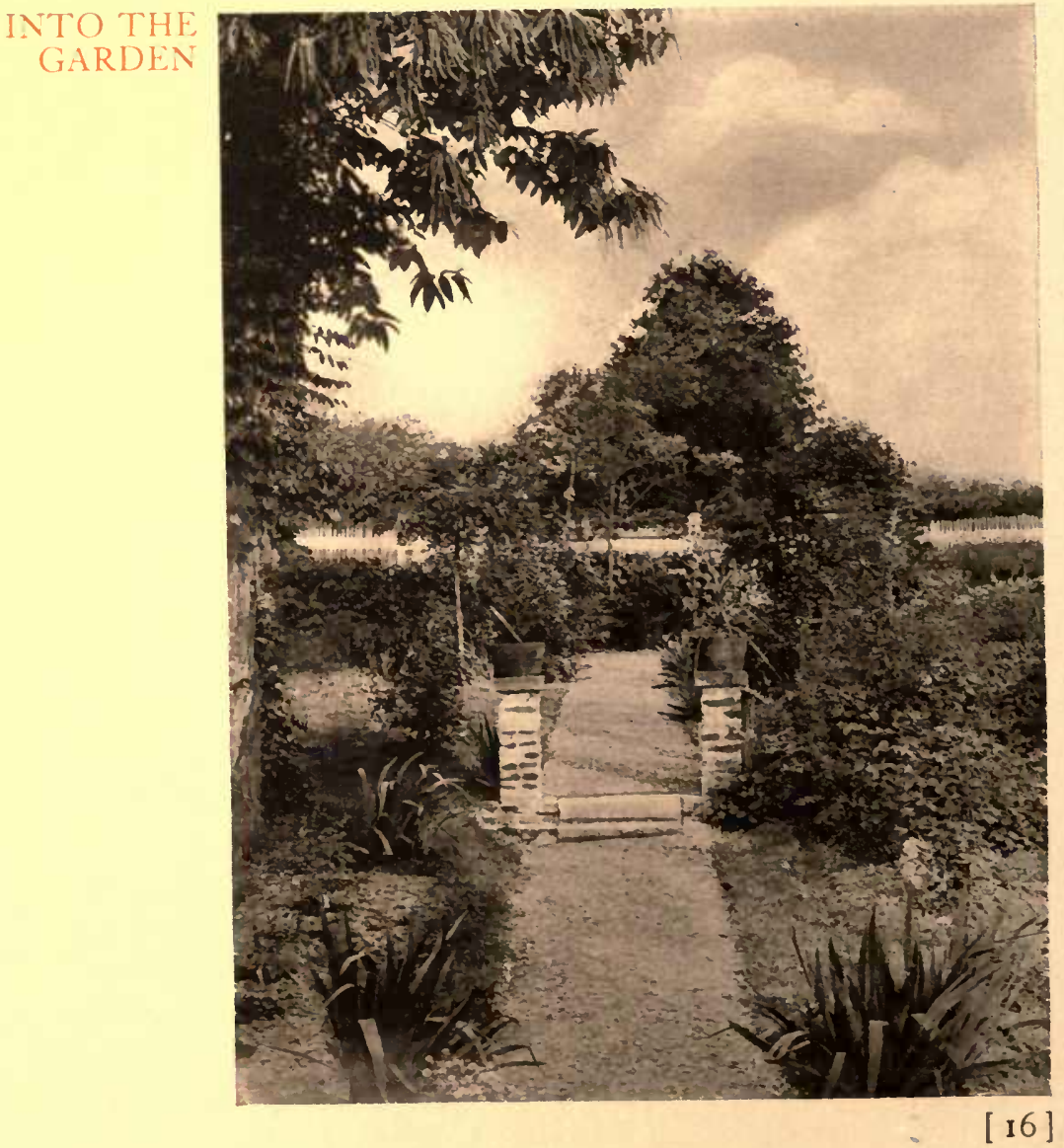




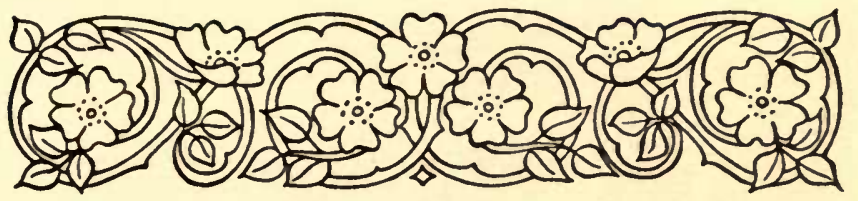

THE

\section{THE GARDEN}

THERE is a very ancient book in which it is said that "the Lord God planted a garden eastward in Eden and took the man and put him in the garden in Eden to dress it and to keep it." The Bible narrative opens with a picture of a man in a garden. The story of Humanity begins there. Was it there that God meant to train man for his great career?

A little farther on in that old book we read that when the man and the woman whom God had placed in that Eden had learned to know the bitterness of sin and fear, "they heard the voice of God walking in the garden in the cool of the day." Is the voice of God still heard in the garden? Is it in the cool of the day, when the fret and fever of life pass with the day's glare, that we are most likely to hear the [17 ] 
Voice? I am sure that it is so, and perhaps that tells us why we so of ten see the parson in his garden.

It is true that our love of the garden grows as we grow in maturity and serenity of soul. The garden has its ministries of hope and peace for the troubled mind, and must not he, whose purpose and work in life is to minister to the troubled mind, himself have hope and serenity of soul? It is a fact witnessed by the soul of man in all his history that there are such ministries of plant and flower, that there is a close bond between nature and man, a bond that makes those ministries real.

That which mainly accounts for the charm of the garden is, I think, the fact that the garden is something apart. It is due to a true instinct that the real lover of the garden refuses to make it an open and public display, and with wall or hedge closes it in and withdraws it from the world's busy life. The garden is a place to which the tired in body or mind may come for calm and peace, and many souls have 
there regained mental balance when great sorrow had come to them.

What it is that in the quiet of the garden ministers to the soul is not a matter of doubt with those who have found peace and serenity there. It is something mystical that draws us nearer to those realities which in our deepest moments we know are the realities of greatest moment to us, but which, in the rush and struggle of life, are so apt to fade from our vision. For it is in the silence of the garden that its ministries are most real to us - at night, when the moonlight throws its soft veil over the sleeping flowers, or in the early morning,

Then to come, in spite of sorrow,

And at our window bid good morrow,

Through the sweet-brier or the vine,

Or the twisted eglantine.

It is then that we most feel the beauty of all things that God has made, and find in all the divine spirit of love.

I have said that the garden is something apart. It is a small part of nature brought [19] 
THE VOICE OF into closer relation with us than the vast exTHE GARDEN panse of earth and sky. It is this fact that explains at least in part the peace and calm so of ten found in the garden.

I think we touch here one of the deepest mysteries of nature. There is much in the external world that is terrible or unfriendly to man. In her vast immensity nature seems outside and beyond man, aloof from his hopes and fears, his joy and sorrow, his strivings and aspirations. How profoundly we realize this when we look to the clouds or the stars above us, in the wilderness where no man is, or in the presence of the great mountains which seem so impassable and unchangeable! At such times nature seems altogether heedless of our feelings or our destiny. This sense of nature's infinite side of ten lies heavily on our souls, and our increased knowledge of her processes makes the contrast between the warm and tender human heart and her cold and impassive, almost relentless, elements dominate our imagination. It is this aspect 
of external nature which made the poet say,

Nature, an infinite unfeeling power,

From some great center, moving evermore,

Keepeth no festal day when man is born,

And hath no tears for his mortality.

But in the garden we get another and wholly different view of nature. Here she comes near to us and speaks in tones of tenderness. Out of the vastness there seem to come, clothed in beauty, messengers to tell us that the Infinite Power is not unmindful of the small and seemingly insignificant, but that He clothes the flower with beauty and feeds the birds that nest in the trees. Here nature comes near to our human sympathies as if to enable us to "see in to the life of things," to give us proof of the wisdom and goodness of the Creator, and help us to know that what we see in the beauty and gentleness of the flowers is part and parcel of a Love which "moves the sun and the other stars." It is the gentler aspects of nature that in the garden soothe and calm the fretted soul, that make us partakers of [2I ] 
That blessed mood

In which the burthen of the mystery,

In which the heavy and the wearyweight

Of all this unintelligible world

Is lightened.

But it is asked, is not this, in the light which science pours upon the garden, after all a very superficial view of nature even as we see it in the garden? Do we not find, even there, the struggle for existence, the strong killing off the weak? Is not the very soil in which your flowers grow rich in mold that tells of the death of countless ages of plant and flower? Yes, it is true. "Every blossom of beauty has its root in fallen leaves." But "there is a smell of violets o'er the mould.'

There is a life that survives, and science has given us a wonderfully illuminating word, a word which enables us to find in dea th itself the pledge of fulfilment for our highest aspirations. Science is teaching us with a great emphasis that life is an "evolution" from lower to higher forms, and that it is the law of its progress that 
the lower passes, that the higher may come to realization. What we call death is the condition of progress. It is a mark of advancing life.

What a wonderful story science tells of the progress of life from a simple cell, the most rudimentary form of life, "mounting from level to level on the ladder of progression," until it has reached man! In that minute cell "were held all the possibilities of physical and spiritual development which we see manifest in cultivated, Christianized man and woman of today."

And what a page of prophecy it unfolds! Is not Victor Hugo entirely sane when he says, "I am the tadpole of an archangel"? He is entirely sane. And the prophecy and promise includes all life. While it strengthens our sense of an immortal life, it includes the idea that all life is spiritual in its essence, and that it is all pressing upward for a higher and still higher manifestation. It gives us ever-growing confidence of that

One far off divine event

To which the whole creation moves. 
One of the deepest effects upon us of the gentler aspects of nature is a feeling or sense of constancy in its relation to us.

We pass through the changing year, the coming of the old favorites in the springtime, the glory of the golden summer, the deepening shadows of autumn, and on into the cold of winter, not doubting that the flowers which seem to die will bloom again when they wake from their sleep. We do not fear that we shall not greet the old friends at the end of their night; and somehow the feeling grows that the mysterious Power, which in some of its aspects seems stern and hard, is kind and may be trusted. The flowers help us to believe the great Teacher who assures us that that Power is our Father.

It is true, there are those who see no such truth in nature. What was true of Wordsworth's Peter Bell is true of them-

A primrose by a river's brim

A yellow primrose was to him, And it was nothing more. 
The mole, burrowing in our garden beds, knows nothing of the hyacinth beyond the fact that its bulb is sweet and wholesome to his taste. He sees the bottom only and knows not that this bulb is only a kind of starting-point, while the best part of the plant is above ground. So there are people who see and enjoy only the material facts. They do not see "the flower on the spiritual side." For them the garden has no mystic meanings. They do not hear the voice of God in the cool of the day. The poet's protest must be that of all souls sensitive to the divine touch-

A garden is a lovesome thing,

God wot,-

Rose plot, fringed pool, ferned grot,-

The veriest school

Of peace, and yet the fool

Contends that God is not-

Not God! In gardens when the eve is cool?

Nay, but I have a sign,

'Tis very sure God walks in mine. 

ART IN THE GARDEN 

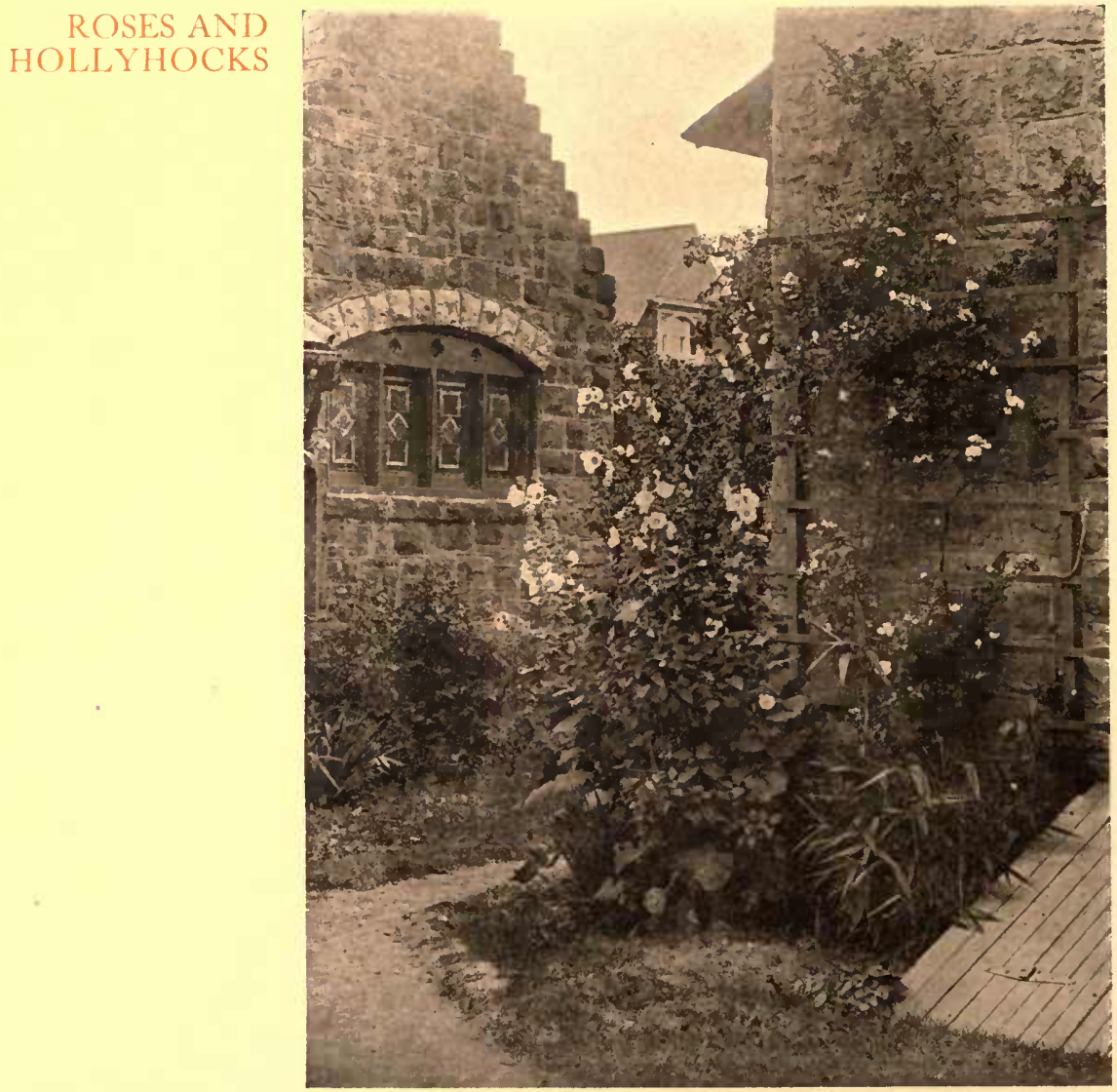

[28] 


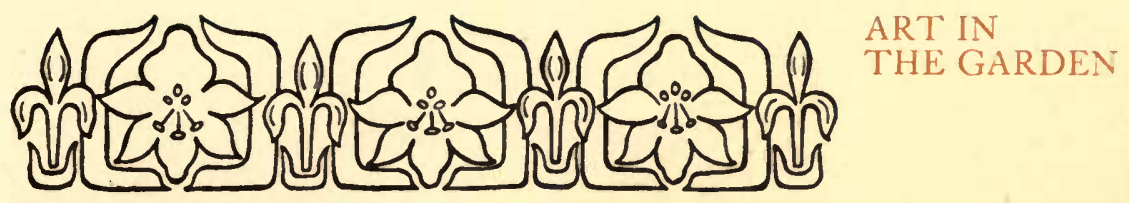

\section{ART IN THE GARDEN}

The GARDEN as something "apart" implies human appropriation and control of nature for human purpose. It may be a work of art as truly as a painting or a cathedral.

There is no such thing as "the art of nature." Nature in the wild is not artistic. Its beauty is instinctive, spontaneous, unpremeditated. Whatever of art we see in nature is imaginary; we read it into nature by selection of details and grouping according to art methods. Nature in the garden is nature tamed, cultivated, made subservient to human purpose, brought into subjection to conscious purpose. A garden is not merely a piece of nature fenced in near the house, like a wolf chained at the back door; but nature cultivated and trained like a dog tamed and trained [29] 
THE YOICE OF for human ends. Art in the garden is the human element appropriating and elevating the natural for human purpose.

This does not mean that nature is to be denaturalized or cultivated contrary to its instinctive purpose, but that the instinctive functions of nature are to be lifted into the higher human sphere. The great end of art is not merely to enable us to see the beauty of nature but to take the material of beauty which nature furnishes and weave it into a higher beauty expressive of human personality.

The very idea of the garden requires that it be beautiful. This is its first demand upon the artist, and for this work he is rich in material, for he is to produce not merely representations of nature, but show us the living things of nature in such relations as will enable us to see them in their greatest beauty. He is to bring them within the human sphere, so as to enhance the beauty, not only by cultivation, but by association which shall make them expressive of human sentiment and feeling. 
Here is the essential requirement of art in the garden. The life of the garden must be understood and its laws obeyed, or disaster will overtake us. In the garden we deal with living things, and we must learn from them the laws according to which they exist and thrive. This done, the living things will yield themselves freely to our hands, and reward us with a wonderfully enhanced beauty.

The form which art in the garden must take depends upon purpose. The kind of garden to be made determines the idea or sentiment which is to be given expression.

There is a vast difference between the requirements of a public park or the grounds of a large estate and those of the more modest home garden, and it is the home garden and its intimacies that we have in mind in these pages.

It is also true that the environment of the home garden may require more formal treatment, or less, as the case may be; but the important thing is that the home garden shall express the home idea and the home feeling. [3I ] 
THE VOICE OF It may also as properly reflect the individuality of its maker as does the house or its furnishings. Above all, it should be evident that the garden is part of the home, as really and evidently so as is the house itself or any room within the house. The plan must include the whole home area. Here we find the main formative principle of art in the garden.

This sentiment which we call the home feeling absolutely forbids public display. Its first demand is the demand for privacy. The garden should, therefore, always suggest retirement. This marks the garden as peculiarly one's own, and makes of it a kind of sanctum. Otherwise it might as well be public property.

If the desire for retirement is to be gratified, if the garden is to be something apart, it must have definitely marked boundaries. They separate the home from the outside world. They shut out the big world and suggest what home should always be - a refuge, a safe and pleasant harbor. They exclude the vulgar things of the street. Reverence for the sacred 
things of life demands it. Good taste demands it.

The garden should be a resting-place for weary eyes, or head, or heart.

It is this idea of the home that should determine the unity of design for the garden. The home idea requires not only harmony of the parts of the garden itself, but unity as the whole of the home, including house and other buildings and grounds intended for other purposes.

Several things will contribute greatly to this effect. The house should with appropriate plantings be "tied down" to the ground, as if it grew there as part of the design. The expert will tell us how to do that most effectively, but the one thing to be kept in mind is to make the house so manifestly a part of the design that one cannot think of the garden without the house, or of the house without the garden. Then the approach to the house and the walks leading from the house to the more retired parts of the garden may be made to contribute [33 ] 
THE VOICE OF greatly to the impression of unity and the feeling of home. Especially should the garden be open to view from doors and windows, that in all seasons and in all kinds of weather one may realize the oneness of the home. In other words, the relation of house and garden should be close, so that passing from one into the other will be as natural as passing from room to room within the house.

The garden itself should have an air of repose. As we enter some room of the house with a sense of its air of more personal interest and privacy, so we should be made to feel as we go in to the garden that here is a place apart from the world's busy life where we may find rest and peace. We should find what John Henry Newman meant by a "garden mystically." It should be "a place of spiritual repose, stillness, peace, refreshment, delight."

For what we call expression in the garden, as well as in the house, nothing is more essential than a certain air of refinement always recognizable. The requirement whether in house 
or garden is an educated taste. In the garden it will be seen in the selection of plants and

flowers and their grouping, and in the sparing use of architectural decorations. It forbids anything that produces confusion. It removes angularity and harshness. It reveals itself in gracefulness of lines, easiness of transitions, and in sparing use of striking contrasts. It will not permit the grotesque, whether in plants or fantastic arrangement of beds. It refuses to give room to the eccentric. It always recognizes the fitness of things.

It follows that to express successfully what I have called the home feeling there must be present that element in pure beauty which is called simplicity.

Simplicity is the opposite of ostentation, extravagance, elaboration, all sins against a refined taste, whether within the house or outside of it. We need, however, to discriminate. Simplicity does not mean poverty of expression. It does not require that the design be bald or severe any more than it requires a face [35] 
THE VOICE OF to be dull, tame, and void of expression. A THE GARDEN refined taste does not exclude richness and polish in the furnishing of a house or garden. It does not mean bareness or a dearth of flowers. What correct taste demands are purity and right feeling in the expression of sentiment.

In the garden the grace and charm of nature should be at their highest, and here the artist of the garden has his finest work to do. While, perhaps, his hand should seem to touch it lightly, yet here the touch must be most effective. Here is where beauty in form and beauty in color will contribute most; yet if care be not taken they will jar with a sense of perpetual discord. It is here that we find the soul of the garden, and it should have that play of features that constitutes its life, its spirit, and its charm.

Truest simplicity is entirely consistent with variety and artful arrangement of groups of plants, producing different vistas from different points of view, and providing delightful retreats in shade and little nooks where some 
of the sweetest flowers delight to grow and blossom. While a good open lawn is indispenART IN sable, plants may be grouped, where space permits, that through and among these may be smaller glades, giving the place that air of indefiniteness so alluring to the meditative mind.

To repeat, the garden must be beautiful. It is the task of the artist of the garden to help us to see its beauty at its highest. To this end nature contributes two elements-beauty in form and beauty in color. These elements of beauty appear in different proportions in different kinds of art, and human appreciations of them differ. It will be enlightening to note how nature uses them. She makes free use of both, but not without some sense of proportion. She lightens and glorifies her forms with all the tints and tones of color, delicate and chaste here, rich and flashing with glorious beauty there; but no one can study a landscape, or a small section of it, without seeing how greatly its grace and charm are due to its lines, now wavy and undulating, again straight [ 37 ] 
THE VOICE OF and stately, opening exhaustless stores for the THE GARDEN imagination. This seems to be the groundwork in nature's plan, and it should be the main consideration in a plan for the garden. It will determine the main features of the garden, the direction and curves of its walks, the position and outlines of all the clumps and beds.

It is difficult for me to imagine a garden without flowers, yet I do accept the very revolutionary statement of a recent writer on landscape gardening that "a garden may be absolutely flowerless and yet be lovely," and that "one may have a world of flowers and yet have no garden in the true sense." I am very sure that the loveliness which the flowers contribute to the garden is wonderfully enhanced when we give them the place that this writer gives them. She holds them to be "the garden's jewels - the bright gems with which its design is embellished and 'picked out,' as a jeweler would say." This idea requires that the flowers be given a proper setting and 
worked into proper relations with plant life in the garden, just as the jeweler brings out the beauty of ruby or opal in the setting or pattern in metal in which he places it.

The controversy between the two great schools of landscape architecture, the formal and the informal, need not confuse us. The simple fact that the home garden must be related to the house, which is artificial and formal, requires a more or less formal treatment of the garden, especially in the approach to the house and the carrying out of architectural lines from the house outward and into the garden. This is required by the fundamental laws which govern proportion and design. It is necessary to a natural and logical transition from the artificial structure of wood or stone to the creations of nature in the garden. The garden mediates between the house, the most formal kind of art, and nature, which is entirely lacking in art. The garden makes the house and home a part of the larger life of the world, binding them to nature, at the same [39] 
THE VOICE OF time that it preserves its privacy and aristocracy, showing man above and supreme over nature.

If the garden be too formal it makes the home too separate from the larger life, too conventional, "unnatural." If it be too natural, and careless, and artless, it fails to mark that rising above mere nature by culture and cultivation which art symbolizes, and which civilized home ought to mean.

It is this evidence of intelligent human control of nature that gives to the formal in art its severe and stately beauty. It imparts to the garden a dignity which it could not otherwise have, and for that air of repose which every garden should have there must be an impression of dignity. But if the beauty be lacking in the grace and charm which greater freedom gives to plant and flower we do not find in it that refreshment of mind and heart which we seek in communion with nature.

It would seem, therefore, that the most completely satisfying style is what one has aptly 
called the "gardenesque," a combination of ART IN the formal and informal in such a way as to set

the garden apart from untamed nature, and yet give us its informal grace in a certain freedom of growth permissible within a more or less formal design.

Something of this we should seek to realize in our gardens. But that is not all that we may have. The beauty of form and color merely as such does not constitute the whole of the charm of your garden and mine. The garden implies the human presence and interest. It is a place for thought and for dreams, and as we grow in intimacy with the flowers and better understand their language, they come to have a new and higher beauty. It might be called the beauty of suggestion. We link the material with the spiritual world, and the more intimately we enter in to the life of nature the more surely does the material become spiritualized.

That which I hold to be the main formative principle of art in the garden - that which uses [4I ] 
nature for the expression of human sentiment and so humanizes and spiritualizes naturemay be worked out in many ways. One way to accent this human element in the garden is to place in it accessories of the nature of garden furniture. Of course, unless the garden be spacious, it is a mistake to crowd in such accessories. But no garden, however small, is altogether complete if it lack a seat or two located in some spot conducive to quiet thought, with some fragrant thing, such as the Sweet Brier, growing near, and some charming bits of the garden to be easily seen. And whatever else is missing in the garden, the sun-dial must not be lacking. The sun-dial has been beautifully called the "garden altar." Is it not fitting? Nothing so impressively sounds the religious note of the garden. "There is a mystery of eternity in a sun-dial" as it marks the shadows passing. "Amidst ye floweres I tell ye houres" is a very old motto for the dial face, and nothing tells us better of life passing on into eternity. The sun-dial should be placed in the very 
heart of the garden, that from it we may look in every direction.

Such is what I have ventured to call the beauty of suggestion; but there is another element of beauty of spiritual quality which the garden may have in a high degree. As the garden grows, association touches it more and more with a spiritual beauty. Each plant, as we watch and care for it, acquires a little history of its own, and about many a spot or plant tender memories of those we love are gathered. And so our gardens become rich in poetry and history.

This is why for me a garden must have trees, if possible old trees, in it, for nothing in nature suggests so much of the spiritual, nothing so gathers traditions about it, as do the trees. A garden without trees must always be incomplete. It is music lacking the strong chords that give dignity and deep harmony to the composition. Lacking the shade and shadow, the landscape composition in an esthetic aspect falls as far short of fulness and meaning. [43] 
But for me there is deeper reason for the trees in my garden. Sentiment demands them. What so human as an old tree around which family traditions have clustered for generations! What in nature so spiritual as the etherialized trees on a winter evening when twilight settles down chill and still, or the lengthening shadows of a day in summer as it grows toward the night! Then too the garden has its voices, not only of suggestion, but actual audible voices, most of which would be lost to us were the trees not there. The birds, where would they nest but for their homes in the trees?

How we would miss the call of the robin from the tree-tops, or the pretty plaintive notes of the blue bird! Poor indeed is the garden in which birds find no homes. And the wind, that "oldest of master musicians," how we would miss his hymnings among the dark leafage! What would the garden be without the green of grass and the sheltering trees with the shadows as they come and shift and steal away? 
This beauty of association can hardly be thought to come within the scope of the artist's work. It is a spiritual quality. It is a matter for spiritual perception rather than visual. It must come with the growth of the garden. It will be part of its history. But if the architect of the garden has the soul of the poet, as he must have to be an artist at all, he will know how to give the whole an atmosphere in which such sentiments will be at home.

After all, the real lover of the garden will make it with a view to in timate friendship with the living things there. The true lover of nature will know my meaning. Others will not. There are those whose eyes are wide open and they see accurately and quickly, but the soul is closed. Some of us want a chance of dreaming. There are those who care little or nothing at all for what cannot be seen with eyes, touched with hands, and expressed in color. Others value the numberless shades of feeling which come to them as they linger among the things of the garden. 
The garden should be, not merely a picture to look at and admire, but a home for the beautiful living things. If flowers have, as I believe, a language of their own, we want to be on familiar terms. We want to get close to them where we can bend the ear to hear their tones. I like, when I walk in my garden, to find my friends in the familiar places; a quiet, shady spot here, a little nook there, where each sweet face looks up to me as if they knew as well as I some fine secret not to be told aloud, but learned by such as love the gentle flowers.

It must be evident that the garden, the real, the satisfying garden, cannot be made to order. It must grow. Not only must the plants and trees grow, but the garden as a garden must gradually take on character as the soul of its owner and maker gives expression to the sentiment which inspires his work. I have said "its owner and maker," for in the end one must make his own garden.

I value greatly the work of the real landscape architect. He can do for us what most of 
us cannot do for ourselves. He should be trusted to determine the leading features of the place and the relative importance to be given to its parts, but the details should be determined as the garden develops, and if the homemaker has the true instinct, his plants will gradually appear where they are most expressive of the best emotions.

The landscape architect can give the human element to the garden, that is, he can mark out its chief features in relation to the home; but only the owner can give the more personal element by making it expressive of his personal soul. It is he who must give it the more delicate artistic touch.

The garden to be a garden must be filled with the personal element. When the architect's work is done, it remains for the one who is to possess and enjoy it to stamp upon it that character which reflects the soul of its maker.

It is not enough that the soul of nature be in the garden. The human soul must be there in acknowledged kinship.

[47 ] 



\section{SENTIMENT IN THE GARDEN}


IN THE ROCK GARIEN

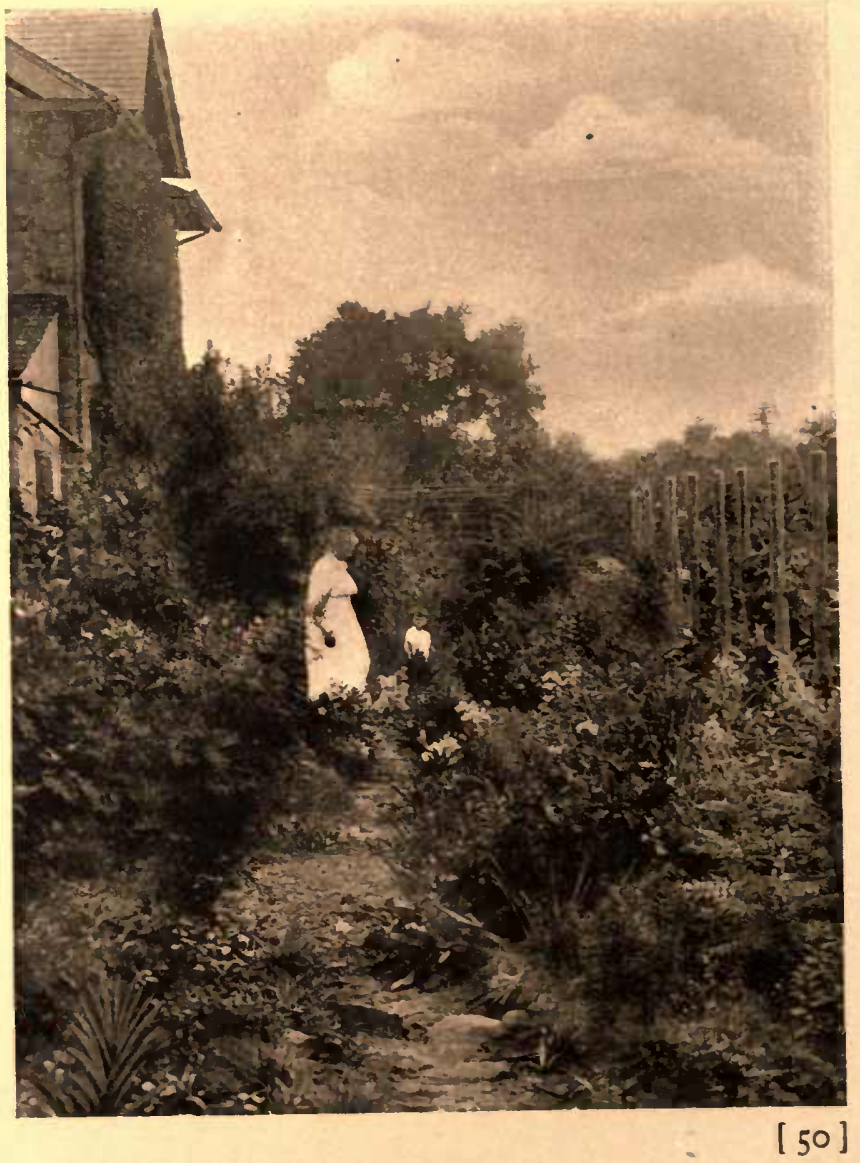




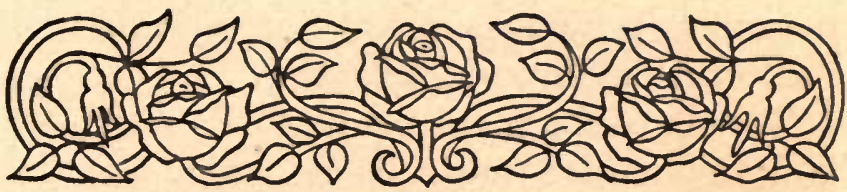

\section{SENTIMENT IN THE GARDEN}

IN MY garden there is a large place for sentiment. My garden of flowers is also my garden of thoughts and of dreams. The thoughts grow as freely as the flowers, and the dreams are as beautiful.

How could it be otherwise? Are knowledge and skill all that is essential to successful work and real enjoyment in the garden?

It is true, sentiment may have little or no place in the work of the expert whom you pay in money. It is true, also, that in the scheme of the practical man of affairs who has managed his affairs so well that he can spend large sums in collecting rare plants and producing elaborate display, sentiment may furnish no motive, may contribute nothing to the pleasure. He may do all that merely because he has cul$[5 \mathrm{I}]$ 
THE VOICE OF tivated a passion for doing things on a large scale, or from love of display.

But not so the true lover of the flowers. For him the garden must be a garden for his thoughts as well as for his flowers. The garden would lose much of its charm, the flowers of their sweetness, and the trees of their mystery, if divested of the sentiment with which the imagination and memory clothe them.

In the garden we face large questions. Is it true that "only to the intimate friend of the flowers are the joys of gardening revealed"? The intimate friend of the flowers! Is there something real in our use of this word "friend" in speaking of a man's relations with the flowers? May we, indeed, carry into our relations with the flowers something like the beautiful reality which in things human we call friendship? Is there in any degree a community of interest and pleasure between plant and man? Is there something like consciousness in plant life?

We are familiar with the sentiment which poets have read into this thought. We recall 
the exquisite lines by Wordsworth in "Early Spring," when, feeling nature linking his human soul to her fair works, he wrote-

Through primrose tufts, in that green bower,

The periwinkle trailed its wreaths;

And 'tis my faith that every flower

Enjoys the air it breathes.

The budding twigs spread out their fan

To catch the breezy air;

And I must think, do all I can,

That there was pleasure there.

That the plants are conscious, that they are capable of "pleasure," enjoying the air they breathe, that is the poet's belief; not a pretty fancy, but his serious belief, for in these lines we have the essence of Wordsworth's nature. Is it possible, then, not only that man may be the friend of the flowers, but that the flowers may be friends to him?

Does Longfellow touch reality when he says-

In all places, then, and in all seasons,

Flowers expand their light and soul-like wings,

Teaching us by most persuasive reasons

How akin they are to human things? 


\section{THE VOICE OF Is Browning less sane than elsewhere when he declares,}

For many a thrill

Of kinship I confess to, with the powers

Called nature; animate, inanimate,

In part or in the whole, there's something there

Manlike, that somehow meets the man in me?

Or Emerson when he says, "The greatest delight the fields and woods minister is the suggestion of an occult relation between man and the vegetable. I am not alone and unacknowledged. They nod to me and I to them"?

Of course, poetic reflection is not scientific evidence. But does the scientist, by his methods, discern the deepest and highest truth of nature? Do we not all at times realize that for real interpretation of nature there must be the soul of a poet and the gift of an artist? The artist often tells us that in his pictures he has striven to express what he calls the "moods of nature." Of course, it may be said that the artist means merely his own moods as they 
are aroused by nature. But may there not be a deeper truth in the artist's use of these words? May it not be that to his truer sight, and because of his profounder sympathy, nature reveals more of her mysteries?

Still, let us ask Science what it has to say upon this subject. Does modern science have anything to say? The fact is, prominent scientists are saying some startling things. For example, Darwin, son of the great Darwin, as president of the Royal Society of England, in his annual address several years ago, declared his belief that plant life is conscious, and he is reported to have made the statement that it is "possessed of faculties up to memory"; and many biologists and psychologists share his views. Many will recall the elder Darwin's fine enthusiasm, who, while always strictly scientific in his methods, never stating anything but uncolored fact, was filled with wonder and awe in his study of the lives and conduct of plants, indicating to his mind something much like human intelligence. 
THE VOICE OF THE GARDEN

It is true, there may as yet be insufficient evidence of a decisive character, as the scientist understands evidence, of the correctness of Darwin's view, but there are indications which no true scientist will ignore. All recognize certain responses of plant life to various influences which are "selective" rather than mechanical. Consider the beautiful adaptations by which plants have secured favorable conditions, adaptations which, to use the elder Darwin's words, "in manifold ways transcend in an incomparable manner the contrivances and adaptations which the most fertile imagination of man could invent."

Consider how the roots of a plant choose from the soil the food which it needs, one selecting lime as its preferred food, another magnesia, another potash. What close observer of plants does not know that they are sensitive, and under certain conditions even irritable? Observe them in their work and in their rest, when they wake and when they sleep, and see whether there is not something there very 
much like nerves. We know how the Sensitive Plant will at a touch shrink like a hurt thing.

That this plant has something like a nervous system seems to be proved by the fact that narcotics weaken its sensibility. It may be put to sleep with chloroform. If opium be sprinkled upon it, it ceases to feel irritants. When anysudden irritant affects it, it will quickly close its leaves, and if the same influence continues, it will resume its open leaves, as if it had been surprised at the sudden touch. On a fair day a few drops of water will cause the leaflets to close, but the plant soon becomes accustomed to a continuous spray and the leaflets remain wide open. An eminent botanist says that if one of the plants be placed in a wagon the jar will cause it to close its leaves, but after a drive of a few miles the leaflets will open, as if it said to itself, "There is no harm in this kind of jarring."

It has been noticed that when the sleep of plants is broken for several successive nights, or when violently shaken by the wind in the afternoon, they suffer from insomnia as we do. [57] 
THE VOICE OF Fasten open their leaves and so prevent their repose, and they will wither and die.

The philosopher, too, has a word to say on this subject. For where is to be drawn the line between conscious and unconscious activity? Philosophically it is more probable that all life is conscious in different degrees than that there is a dualism, part conscious, and part.unconscious.

It would be difficult for us to say what kind of consciousness plants have without more light on the subject; but surely there is abundant room for reflection as we move among our flowers or roam through wood and field.

How far, then, may a sane man who has in his life a place for sentiment press this thought of community of interest and pleasure with his flowers without being merely fanciful?

How far in the evolution of life the plant has come we may not know, but I am far from denying what the poet has long loved to believe and the scientist now tells us may be true. 
I do not find it very difficult to believe, with one of the ancient philosophers, that plants IN THE GARDEN have mind, pain, pleasure, desire, even knowledge.

This much is true, both the poet and the scientist compel deeper reflection, and give to the things which appeal to my senses a more spiritual quality. I am sure that no sane man can touch such questions as this without a sense of awe. In the presence of the tiniest blade of grass or the simplest flower we face the great mystery, the mystery of life; and all life, I must believe, is spiritual in its essence. The plant is simply a lower form of the same divine energy which is in man, and is groping, as Emerson says, "upward towards consciousness." Surely there is occasion for wonder, and something of the reverence which Tennyson felt before the little flower in the crannied wall-

Little flower-but if I could understand

What you are, root and all, and all in all,

I should know what God and man is. 
It becomes a man to consider the humblest flower that grows with a feeling of reverence and worship, for it is itself a thought, a plan, of God. And more than that, for to it God has given something of Himself. He has given life to it.

There is nothing in the paintings of the great masters, nothing in statuary, nothing in the most elaborate decorations of architecture, to be compared with the simple grace, the delicate tints, the perfect harmony of a flower.

The glories of art are dead things, but the little flower is filled with the divine energy of life; and as we look upon the world more widely, and into its secrets more deeply, we are more and more compelled to confess but One Life pervading the universe.

This little excursion into the region of philosophy has shown us that the garden does furnish cause for the deepest of all sentiments, wonder, reverence, and worship. The flowers bring the soul of man into an attitude receptive 
to spiritual teaching. They teach humility and faith.

What beautiful thoughts grow in our "garden of thoughts"! The flowers and the thoughts grow together. Sentiment gathers about them as surely as their own perfume. The very history of the plants is full of poetry and romance.

To write the romance of "Social Botany" will require a gifted pen, and when written it will be an entrancing tale. Go into your garden and ask your trees and shrubs and flowers whence they came, and they will tell you of seedlings collected in forests and of seeds obtained from the farthest corners of the earth, many of them secured through adventure and peril, the recital of which compels admiration, and brought to their present perfection by a patient application of scientific method in hybridization of which the untrained mind can form no adequate conception.

Who can look upon a "Dawson" rose, knowing its history, and not let thought go back to [6I] 
THE VOICE OF the little garden of the Harvard wizard where he produced, by mating many parent roses, at last an offspring so perfect? One grandparent of the "Dawson" is the "Wichuriana" from Japan, the other the Chinese "Multiflora." Their offspring mated with "General Jacqueminot," and they are the parents of the "Dawson."

Ask your beautiful Irish "Killarney," or your gorgeous "American Beauty," the story of their descent, and they will point to a line of ancestry reaching back in known history to the Crusades. Thibault, the redoubtable Crusader, brought the first of those ancestors from Damascus and gave it a home in the soil of gentle Provence, France. There a son of Henry III of England found it growing, carried it home, and as Earl of Lancaster took it for his device. Rival claimants to the English 'throne adopted it as their emblem, Red Rose of Lancaster and White Rose of York warring, until Henry VII of the Red took Elizabeth of the White as consort. Thus the rose brought 
by the Crusaders from Damascus became the national flower of England, where it has had its most congenial home and developed its highest perfection.

The annals of the rose tell no finer story than that of the mating of the "Sweet Brier," sweetest of all wild flowers, with a descendant of the "Damascus" brought to England in the Crusades. That marriage was brought about by Lord Penzance, and to it we owe the beautiful scented roses known as "Penzance Briers."

How close to us the flowers come! How human and near to the affections they seem! Linger by the old favorites in the old home garden. What beautiful associations they recall, what tender memories cluster about them! The Aster, classic flower sung by Virgil; the Columbine, itself like a cluster of doves; Canterbury Bells, recalling the pilgrims to the ancient shrine; Iris, Ruskin's flower of chivalry, "with a sword for its leaf and a lily for its heart"; the Paeony, flower of distinct antiquity, cultivated since the days of Pliny, [63] 
THE VOICE OF flower queen among the Chinese and believed to be divine by the Greeks; the Tulip, held by Persian lover to be the emblem of his passion for the mistress of his heart; Evening Primrose, strange flower of mystery; Yellow Day Lily, with its pretty old-fashioned name, "Liricon fancy"; the Madonna Lily, white and pure as the name it bears; Rosemary, the flower of remembrance: Daffodil and Primrose, sung by our English poets; Larkspur, Foxglove, Speedwell, Blue Bonnet, Bleeding Heart, Sweet Lavender, stately Hollyhock and splendid Sun Flower, all take us back to the gardens of our childhood or suggest poetic fancies as beautiful as themselves.

The flowers themselves are touched with a finer beauty and exhale a sweeter perfume because of what they are in our thoughts and what they recall. Is not my "Dean Hole" rose the more charming because it bears the name of that great lover of roses, and brings to my mind the many beautiful things he wrote about roses? Who does not love the "wee, 
modest crimson tipped flower" the more because the eye of Burns dwelt so lovingly upon it?

Who would not cherish with tenderness a plant from "Mother's garden" of long ago? Of all the flowers that bloom in my garden none is to me so sweet as the Madonna Lily and the old "Giant of Battles" rose-my Mother's favorites. How much closer would the association be if the plants themselves could have been brought to my garden from that which the Mother tended, but that could not be, for the hand of time has long since brought great change to the old home garden.

One lover of gardens has a son in far-off China, who, before leaving his home, built a pergola in the rectory garden. That pergola is now covered with Chinese vines, and about it are grouped fine specimens of oriental shrubbery, planted there in honor of his work so far from those who love him best. Does not the sentiment which prompted the planting and nurture of those plants add a spiritual qual[65] 
THE VOICE OF ity to that garden? Do not the associations THE GARDEN which they recall and the memories which they enshrine make them richer in true values than the rarest which money merely buys? And so my garden is more and more a garden of remembrance.

While writing these pages I have had in mind a truth as wide and deep as life.

"The love of flowers," Dean Hole says, "is innate." It is true. The little child needs no instruction from books or teachers to look with delight upon the flowers. Hard-working men and women, though shut up in garrets and crowded streets and noisy factories, will grow a little plant or two in the window and watch with pathetic pleasure the opening blossoms. Is it true, also, as the good Dean says, that this innate love of flowers is "a remembrance of Eden"?

Has God put these beautiful flowers everywhere in man's path to remind him of a lost Paradise, and to keep alive hope of a Paradise to be regained? It would seem to be even so, 
for He who came to reveal the Father pointed to the flowers to teach the greatest of all lessons, the lesson of trust in God, when he said, "Consider the lilies."

The lilies! They that toil not nor spin! A remembrance of Eden before the toil began!

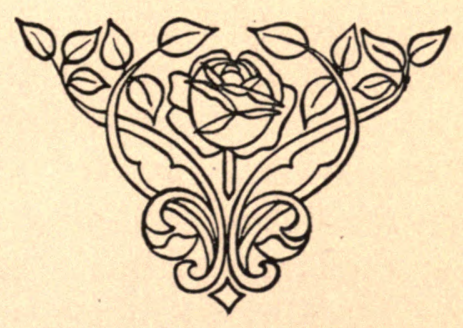





\section{VOICES IN THE GARDEN}


A GROLPOF FAIORITES

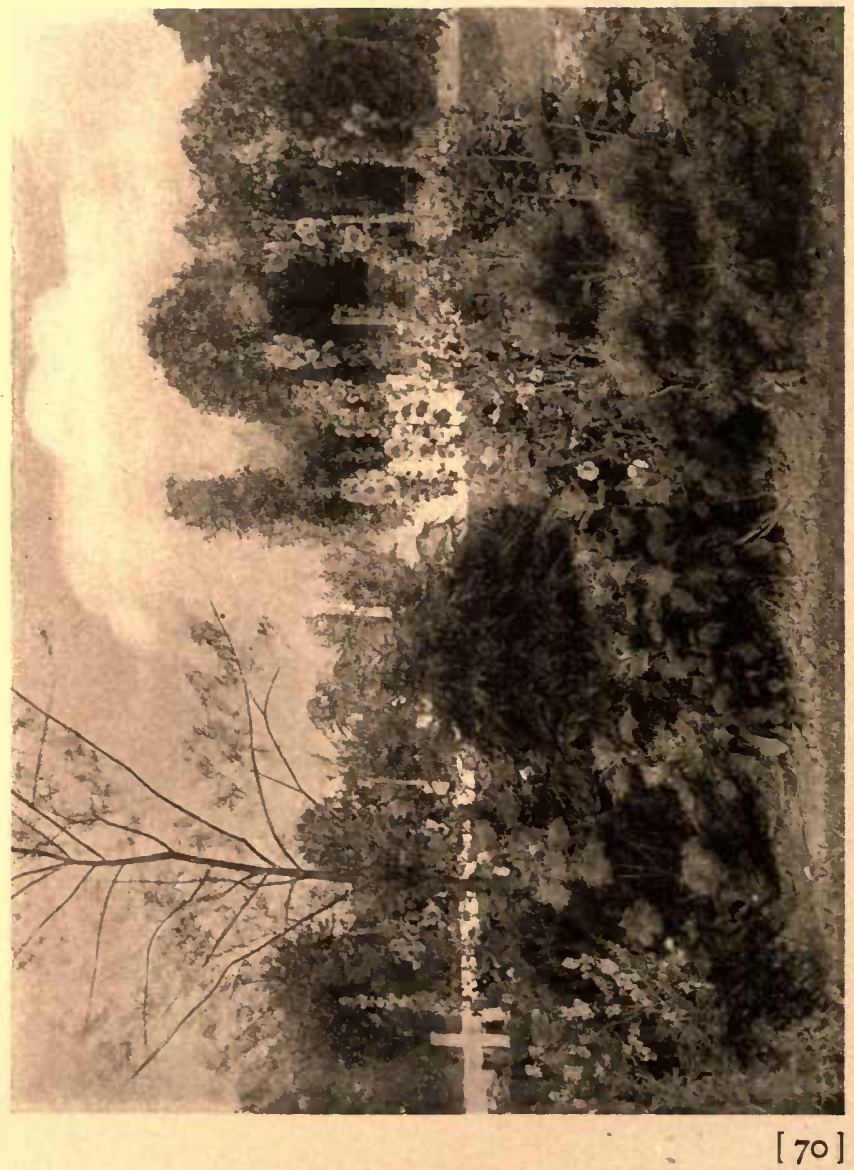




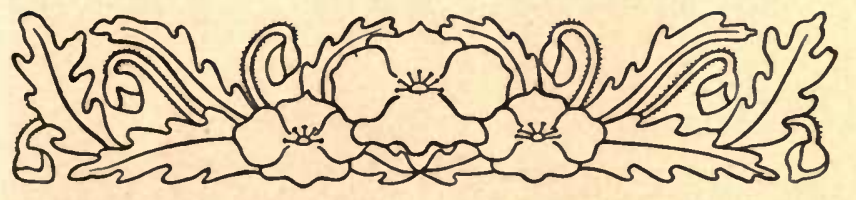

\section{VOICES IN THE GARDEN}

There are voices to be heard in the garden. Some are audible, as in the songs of the birds, the humming of insects, and the hymnings of the wind; but mostly garden voices are heard only by the ear of an imaginative sympathy.

There is a language of the flowers. It is well to question them. They have something to tell us.

I am speaking the common speech of man. The literature of every people reflects it. The language of botany is full of imagery that suggests it, but it is the common names of the flowers that tell best how the mystical meanings hidden in the flowers have made themselves heard in human speech.

It has been said that "the botanical name expresses the plant's standing in the scien[7I] 
THE VOICE OF tific world, and the common name reveals its relation to humanity."

The common names show what the flowers have been to man. How exquisitely poetic many of them are! The Easter Lily, the Violet, Bluebell, Blue Speedwell, Forget-me-not, Buttercup, Snowdrop, Lily of the Valley, Poet's Narcissus, Sweet William, Carnation- " to tell their names is to recite a poem of grace and light."

What a story these names tell of a "long human past behind them"! How affectionately they are named! The whole vocabulary is filled with sentiment in which love delights.

The reality in it all is seen in a fact as old as man and as deep as life-the fact of the influence of nature upon the heart of man. It springs from a sense of the inner life of things and of our relations with them.

Thoreau says that there is a flower for every mood of the mind. He means, I think, not only that every flower in some way answers to something in the soul of man, but that every 
emotion of man finds in the flowers something that answers to it. Hence we find in the common names of so many of the flowers, not only something of the life of the plant and its affiliations, nor merely suggestions of likeness to other things in nature, but of ideal graces and passions expressive of man's loves, sometimes of his superstitions, and often of his religion. Behind every flower of our gardens, and the flowers of the field, is some memory, or in it some suggestion of things deep in the common heart of man. There is in truth no aspiration of the soul which may not find an answering note, no sorrow of the heart for which there is not a message of peace.

There is a mystical side of nature which calls to the soul of man and compels the feeling that there is something that comes through material things that is more than material, that is, indeed, spiritual. It carries our thoughts and feelings out of the material to something akin to our own spirits. There is something that comes through eye, ear and imagination, that [73] 
THE VOICE OF speaks to the heart and conscience. There are hints and intimations of something more than eye, or ear, or mere intellect discovers.

There is hidden, somewhere, in every one of us, the mystic, and to this hidden man, out of the deep mystery, Nature speaks. It may be only when alone amid Nature's vast silences that this hidden man wakes to consciousness. There he touches shoulders with strange things. Some realize this mystical relationship with nature most when in touch with nature's gentleness, but each of us is most conscious of it when most alone with it.

This is what explains the charm of the garden for the dreamer when twilight deepens toward night, and form and color grow less clear to sight, and the sounds of the outside world are stilled. It is then that he knows himself most near to the great Mystery. It is then that he learns most of its meaning, though only a scent with lightest breath touch him, or he hear no more than the rustle of an overturned leaf. The rose of summer, or the leaf of 
autumn, the perfume evanescent as the dreams of youth or lingering as the memories of childhood, each has for this soul its message, sweet, wholesome, and true.

If only we could find words to tell just what the flowers say to us! But they speak a language not easy to translate into our common speech. The thoughts of the flowers reach into the heart of things, thoughts of ten too big for words.

Then, too, the flowers have their high reserves. Few have their full confidence-none who are not clean of heart. Only the real lover of the flowers will understand their speech. What Mrs. Hemans finely says of Walter Scott among his trees at Abbotsford tells the way we must learn their language,-

Where every tree had music of its own

To his quick ear of knowledge taught by love.

There is a converse of the garden that can only be heard by "that inner ear that remembers."

[75] 
Some one has said that the Primrose is "a beautiful eye looking out from the great inner sea of beauty." What does the soul that looks through that eye say to you? I cannot tell. It depends upon what it sees in you.

Go with me in to my garden. It is the call of spring that we hear. Winds from the Southland, melting snows, faint odor of swelling buds, the note of the first bluebird, these are the call of the spring. It means sunshine and beauty. The shadow spots and sheltered nooks are still white, but little sunny knolls in my rock-garden are bare, and green things are shooting up. True, the snow may fly again tomorrow, but a thousand voices proclaim the coming of our old garden friends. Through the mellowing earth and the dead leaves some of them are already thrusting their heads. It is evident that they are expecting us. If you understand and know how to translate, you will hear the voices.

The first to greet us are the Snowdrops, "fair maids of February." Brave little flowers! 
See how they hang out their bells as if to greet the wind. "Our Lady's Bells," we call them, and the name is fitting, for nothing in nature speaks more plainly of courage and purity. We think of that "First snowdrop of the year" which lay on the breast of the nun as on St. Agnes' Eve she prayed for the purity of its snows.

Tomorrow, or perhaps next day, certainly before many days, we shall see the Hepatica open its blue eyes and look up at us from some nook where it has been willing to accept a home, and the Crocus will lift its "chalice cup brimmed with dew." Do they not speak of a purity that "knows naught of fear"?

Look now where the green shoots of the Daffodils pierce the mold and lift their brave trumpets of silver and gold. Do they not tell of a courage that "keeps the heart strong because safe in the Hand that fashioned its beauty"?

Can you not hear, when winds are still, The gay fanfare of the Daffodil? 
The Violets! Who does not love the Violets? Of what dear memories they tell! Who would try to tell what they have whispered in the ears of young love?

Shakespeare says, "Pansiesare for thoughts." Men have called this flower "Heart's Ease." Some one tells how a knot of white pansies was given to a poor outcast of the slums. She looked at them and with a burst of tears she answered them, "I'll try! Indeed I'll try!" Can any one fail to know what the pansies said to her?

Summer is here. Will you be with me in my garden these wonderful days of summer?

Every tree and shrub is rustling fresh leaves. Bird music is at its height. The summer beauties offer us their flowers in blue, and white, and yellow, and rose. The summer flowers! What a chorus of voices greets us! How much they have to tell us! I ask my Hollyhocks, growing there at the end of the path or in yonder corner, and they always tell me that they are there that I may have "a comfortable 
sense of home." I never miss my chat with the "Morning Glories." What gay gossips they are!

How they peer up and down as if eager for news! But they are never unkind in their gossip, and always have a word of cheer for the day.

Maeterlinck speaks of the "loud laughter" of the Phlox, and do we not hear its gay note these summer days?

A recent writer calls the Scarlet Sage a "flaunting braggart." I cannot think it. To me it says, "I bravely wear the color given me by the Hand that fashioned me, and I love to bloom, for I am sent to lend brightness to the world"; and when I give it a proper setting among the green things of the border with some sweet white things near by, its brightness lightens all about it. It is doing there just what I would have my sons do-take their place where God calls them and bravely wear their colors in the face of all the world. If I misplace my Scarlet Sage the fault is mine.

I often find myself lingering where the Mignonette grows. Why is it that this plain little [79] 
flower, for all the world like some dear little old-fashioned lady, is so universally prized? Is it not for about the same reason that we love the dear little old-fashioned lady? This flower seems to speak to every heart. Just what it tells me I am as unable to put into fit words as I am worthily to tell the influence which the dear little old-fashioned lady has upon me. Its clinging perfume is like that of a sweet life lived among us. That, I think, is the secret of its charm.

The Poppy is to me, like the Evening Primrose, a flower of mystery. Men have had many beautiful thoughts about it, and I have had mine. Its sunny face, like a cup filled with light, is as open as a child's heart, but its drooping, sleepy buds seem always to be holding back something. The Poppy fascinates me. It must be the hypnotist of the garden. Its seeds bring sleep.

The Rose! Emerson tells us that the Rose speaks all languages. True aristocrat the Rose is, telling of gentle blood and good breeding, 
yet she has the world's heart for her own. It must be that she calls to something deep in VOICES the common heart of man. Does Dean Hole tell us the truth of it when he says, "If a man would have beautiful roses in his garden, he must have beautiful roses in his heart"?

And the white Lilies! We cannot think of them without thinking of the Mother who holds a stalk of them as she bends her head to listen to the angel of the Annunciation. I cannot tell what the Madonna Lily says to me; it is enough that I feel it.

And so I go from flower to flower, and each has something to tell me. I can understand why men have given them such charming names, "the softest in the language." To me every flower that blooms in my garden, every flower that blooms anywhere, is beautiful and full of meaning. I cannot for a moment accept the statement of William Morris that "red geraniums were invented to show that even a flower could be hideous." I could no more think a flower "hideous" than I could think [8I] 
THE VOICE OF a child so. They both come out of the worldold Mystery, and are parts of a plan that I believe to be good. I think, too, that if we but rightly discern, we will find that "all that lives creates its own harmony."

Yes, there are voices in the garden. Everything that lives has its truth to teach, and if our hearts are attuned to the meaning of things, we too shall hear The Voice that the first man and woman heard in that garden which God planted in Eden so long ago.

Many reverent souls tell us that they have heard that Voice in the garden. Ruskin says, "And so it is with external Nature; she has a body and a soul like man, but her soul is the Deity."

$\mathrm{O}$, see a world in a grain of sand, And a heaven in a wild flower,

sang the poet Blake, and Mrs. Browning wroteThere's not a flower can grow upon the earth Without a flower upon the spiritual side.

Earth is full of heaven

And every common bush afire with God. 
One of the recently found sayings of Jesus is this, "Raise the stone and there thou shalt find me, cleave the wood and there am I."

Do we not pause reverently before such sayings as these? Do they not quicken our sense of divine reality in Nature? Happy is he who walks in his garden with something of the soul of the poet and the faith of the Christian. He will discern, not only the beauty of form and color, not only the beauty of the parts as they relate themselves to the whole, but he will apprehend something of the intimations-the great thoughts-which come to him through their beauty, and which make their appeal to the soul within him. With eyes to see he may see "the flower on the spiritual side." He will discern that the beauty which comes to him through the eye, and the moral light which shines from behind upon the soul, come from one center and lead upward to the thought of One Being who is above both and yet in both.

With reverent soul he will hear the Voice in the cool of the day.

[83] 

OUT FROM THE GARDEN 



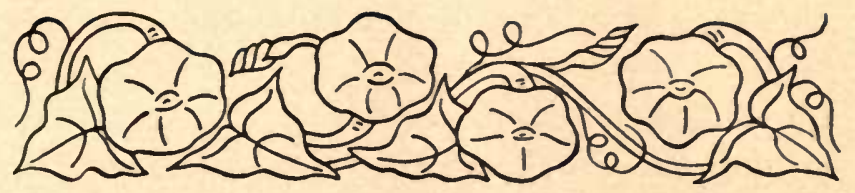

OUT FROM THE GARDEN

This little book but records the thought of one who has tried to translate in part the message which the flowers bring to him. It is a feeling after an interpretation of nature that will answer to the spiritual in man. It grows out of the conviction that in spite of the sterner aspects which Nature often wears, there is also evidence of a gentle Goodness as well as an infinite Wisdom at the heart of things; and in nature nothing tells us this so persuasively as do the beautiful flowers. If this booklet should dispose any man or woman to seek more of the meditative life, to live more in the garden of flowers and thoughts, the writer shall be glad.

But, after all, it is asked, is such a life consistent with the noble "impulse of service" so [87] 
THE VOICE OF characteristic of the better life of our time? It THE GARDEN is often supposed "that to be a nature-lover implies unvexed indifference to the human affairs of the time, and that therefore it makes for a kind of serene and weak utopianism." Does not the impulse of service lead us to the place where men most gather, the city rather than the country, the street rather than the garden?

Most surely, the true ideal for man is not that of the meditative life of withdrawal from common human interests, not that individualistic spiritual development centering the soul upon itself and its moods, but that of service inspired by a sense of community of life and of life's interests. It must not be forgotten that while the Bible story of humanity begins in a garden, it ends with a vision of a city.

But what best fits us for the service of man? Is it not best found in the cultivation of a sane and stable confidence, an unfailing poise and balance of mind and heart? Without such poise and repose we become involved in the 
elaborate artificiality of civilization or engulfed in the turmoil of the world's contending passions. We need inspiration from the direct and natural, rest from the strenuous and complex. We need to go at times where things come naturally and in order.

This is how the garden helps one to be sweet, sane, and warm-hearted. The very intensity of modern life demands such quiet as the garden affords as an antidote and corrective. Nowhere can be better cultivated what one has called the "reverent attitude toward life." Every one who heeds the call to service knows how much we need what the same writer calls "spiritual reactions." How of ten the servant of Humanity is tempted by a feeling of the utter futility of his work! How shall we keep hope alive? How maintain the poise and balance so necessary?

I have found it good to go alone in to my garden. There, too, I find a drama, intense, complex, ever-moving. There, too, are living creatures, with, as Ruskin says, "histories written [89]

OUT FROM THE GARDEN 
on their leaves, and passions breathing in their motion." But there is order. Nothing is purposeless. All are working out their lives to the legitimate end. It teaches me faith-faith in the unseen Power which has directed all things from the beginning, faith in the marvelous forces without which my plants could not live and grow and bloom. It teaches me to put my confidence in One who cares for His creation and steadily works His will. There are times when it is well to be reminded that the universe is in better hands than ours. The One Perfect Man went in to a garden to get strength for His cross.

In my garden I learn a true ideal of service. I discover how foolish is the notion of the earth which men in their selfishness have cultivated. I am taught that it is not true that here on the earth all things exist merely to please man, that the eternal forces work only for him. As I observe the life of the plant and watch its struggle for existence, I am taught a real regard for its rights. But I am taught much 
more than that. I see that the plant does not exist for itself alone. Its one aim is to give its fruits to the future. It exists to bloom and ripen seed, and of ten yields its life in thus giving on in to the future its gifts of flower and fruit. The plant grows and blooms and bears fruit, not for itself. Nothing comes back to it. It ripens its seed only to increase the giving.

Does it not teach us the deepest truth of life? What is a true service of man? What is love? What its glory? Is it not that which is also its pain? The love of a parent never comes back to him, but is carried on and given to the children's children. What is the deepest of all lessons taught by Him who has shown us in Himself the love of the Father in heaven? Is it not that all love is a gift? It came not back to the Man of Galilee and Calvary, but has gone on through the ages, the true disciple always pouring out on others what to him is so unstintingly given.

The teaching of my garden does not end here. The rosebud that greets me in the morn[9I ] 
THE VOICE OF ing will not remain a bud. It must needs burst, for the life within it is so abundant that it can no longer contain it all, but in blossomed brightness and swimming fragrance must let forth its joy and gladden all the air. To bloom is the law of its life, and should the bud refuse to expand, it would quickly rot at heart and die. The heart that refuses to give will as surely wither and die.

My garden teaches me another lesson without which in all service of man our feet would falter and our hands hang down. It teaches me hope for my kind. The growing cactus is not a thing of beauty, but see it when covered with bloom. It is a blaze of light, glorious among flowers. Things human are not always beautiful. There are ugly lives, but shall we not have confidence in a possible bloom, beautiful and good?

The plants in my garden all show a capacity for culture. All these beauties have come from the one original rudimentary form of plant life. And what marvels of beauty there are in our 
gardens that are not so in their wild uncultivated state! What glorious roses that in the wild are sweet, but simple and humble in comparison! Yet, inherent in the wilding is the power of development.

Shall I not go from my garden out among men with a surer confidence in the possibilities of spiritual life?

Is it not well now and then to get away from men and the crowd and go in to the silence where we may hear the Voice in the cool of the day?

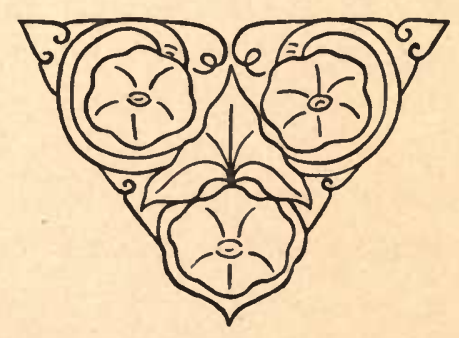

[93] 

Here ends The Voice of the Garden, an interpretation of the deeper meanings of plant life, touched by sentiment, and written by Abram Linwood Urban, as a tribute to his wife, and not first intended for publication. Illustrated by half-tones from photographs of the author's home garden and decorated by Grace Lillian Urban, the author's daughter, the whole was done into a Book for Thomas Meehan \& Sons, of Germantown, Pennsylvania, whose large nurseries, founded in 1854 by the late Professor Thomas Meehan, have so greatly contributed to the growth in the American people of that love of gardens for which the book speaks. The typography and binding were designed and supervised by the Service Bureau of the Wm. F. Fell Company, who printed the book, the whole being done and completed in the City of Philadelphia, in the month of October and the year of Our Lord Nineteen Hundred and Twelve. 





A 0000459610 


\section{$(32)$ \\ 3}

.

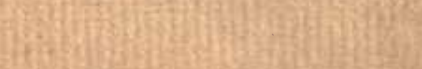

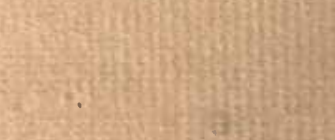

Affly:

atis

(4)

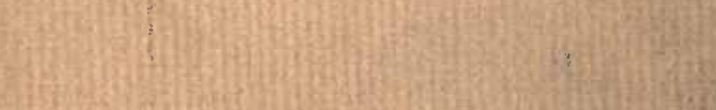

2.

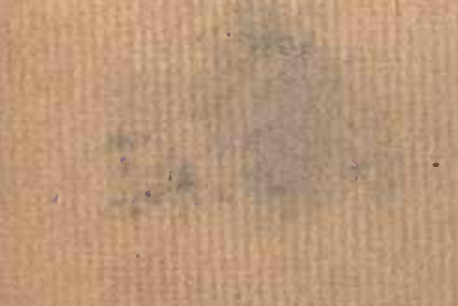

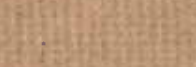

Hal

Sagay

1)(-

$\rightarrow$ 